Analyses of the Reflector Tank, Cold Source, and Beam Tube Cooling for the ANS Reactor

\title{
Scott Marland
}

The University of Tennessee

July 1992

\author{
Prepared by \\ Oak Ridge National Laboratory \\ Oak Ridge, Tennessee 37831 \\ managed by \\ MARTIN MARIETTA ENERGY SYSTEMS, INC. \\ for the \\ U.S. DEPARTMENT OF ENERGY \\ under contract No. DE-ACO5-84OR21400
}




\section{TABLE OF CONTENTS}

Page

LIST OF FIGURES $\ldots \ldots \ldots \ldots \ldots \ldots \ldots \ldots \ldots \ldots \ldots \ldots \ldots \ldots$

LIST OF TABLES $\ldots \ldots \ldots \ldots \ldots \ldots \ldots \ldots \ldots \ldots \ldots \ldots \ldots \ldots \ldots$

SUMMARY $\ldots \ldots \ldots \ldots \ldots \ldots \ldots \ldots \ldots \ldots \ldots \ldots \ldots \ldots \ldots \ldots \ldots \ldots \ldots \ldots$

1. DIVERTER/REFLECTOR TANK: SEALS AND BOLTS $\ldots \ldots \ldots \ldots \ldots \ldots \ldots \ldots$

1.1 INTRODUCTION AND OBJECTIVES $\ldots \ldots \ldots \ldots \ldots \ldots \ldots \ldots \ldots \ldots$

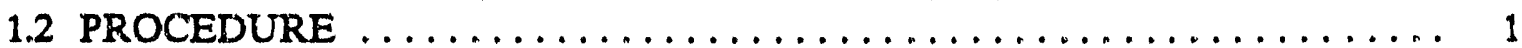

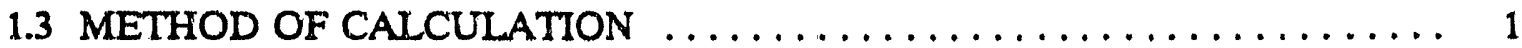

1.4 CONCLUSIONS ............................... 4

1.5 RECOMMENDATIONS $\ldots \ldots \ldots \ldots \ldots \ldots \ldots \ldots \ldots \ldots \ldots \ldots \ldots$

2. DIVERTER/REFLECTOR TANK: LOCKRING $\ldots \ldots \ldots \ldots \ldots \ldots \ldots \ldots \ldots$

2.1 INTRODUCTION AND OBJECTTVES $\ldots \ldots \ldots \ldots \ldots \ldots \ldots \ldots \ldots \ldots$

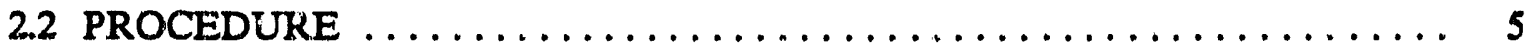

2.3 METHOD OF CALCULATION $\ldots \ldots \ldots \ldots \ldots \ldots \ldots \ldots \ldots \ldots \ldots$

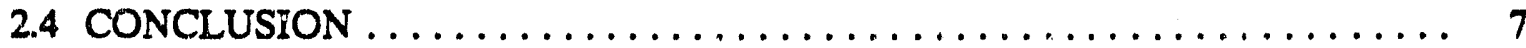

3. COLD SOURCE: WARM D $D_{2}$ AUXILIARY TANK $\ldots \ldots \ldots \ldots \ldots \ldots \ldots \ldots$

3.1 INTRODUCTION AND OBJECTIVES $\ldots \ldots \ldots \ldots \ldots \ldots \ldots \ldots \ldots \ldots$

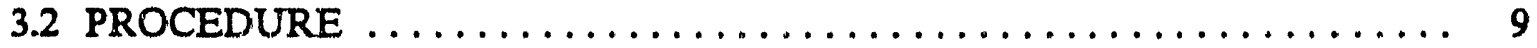

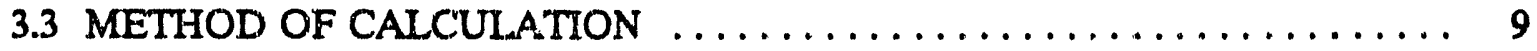

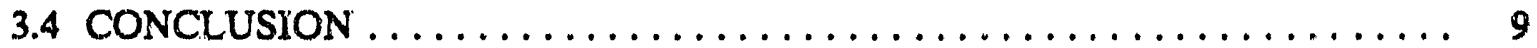

4. COLD SOURCE: CENTER OF GRAVITY $\ldots \ldots \ldots \ldots \ldots \ldots \ldots \ldots \ldots \ldots$

4.1 INTRODUCTION AND OBIECTIVES $\ldots \ldots \ldots \ldots \ldots \ldots \ldots \ldots \ldots \ldots \ldots$

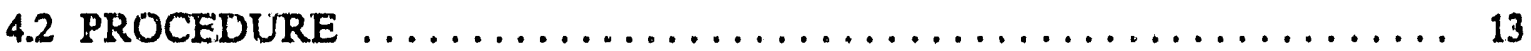

4.3 METHOD OF CALCULATION $\ldots \ldots \ldots \ldots \ldots \ldots \ldots \ldots \ldots \ldots \ldots \ldots \ldots$

4.4 CONCLUSION $\ldots \ldots \ldots \ldots \ldots \ldots \ldots \ldots \ldots \ldots \ldots \ldots \ldots \ldots \ldots \ldots$

5. BEAM TUBE CDOLING $\ldots \ldots \ldots \ldots \ldots \ldots \ldots \ldots \ldots \ldots \ldots \ldots \ldots \ldots \ldots$

5.1 INTRODITCTION AND OBJECTIVES $\ldots \ldots \ldots \ldots \ldots \ldots \ldots \ldots \ldots \ldots$

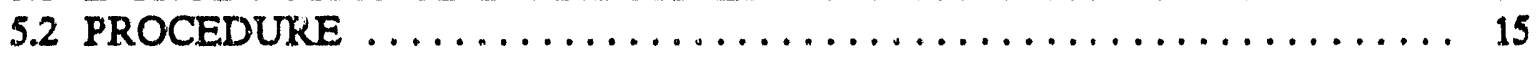

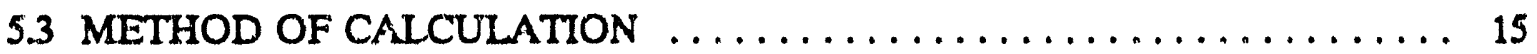

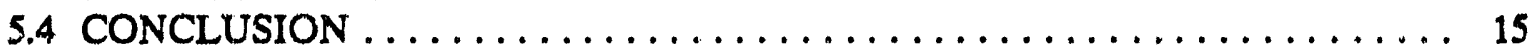

6. BEAM ANALYSIS $\ldots \ldots \ldots \ldots \ldots \ldots \ldots \ldots \ldots \ldots \ldots \ldots \ldots \ldots \ldots$

6.1 INTRODUCTION AND OBJECTIVES $\ldots \ldots \ldots \ldots \ldots \ldots \ldots \ldots \ldots \ldots \ldots$

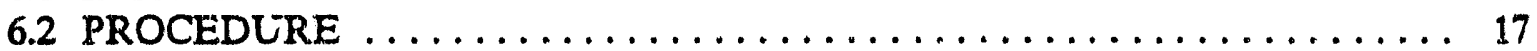

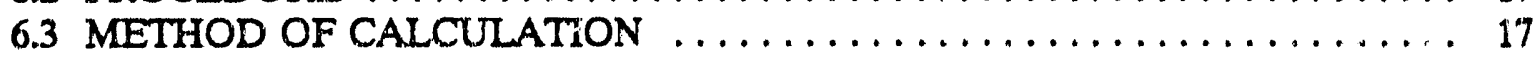

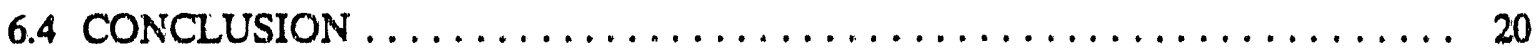




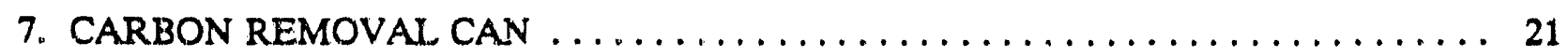

7.1 INTRODUCTION AND OBJECTTVES $\ldots \ldots \ldots \ldots \ldots \ldots \ldots \ldots \ldots \ldots, 21$

7.2 PROCEDURE $\ldots \ldots \ldots \ldots \ldots \ldots \ldots \ldots \ldots \ldots \ldots \ldots \ldots \ldots \ldots \ldots \ldots \ldots \ldots, 21$

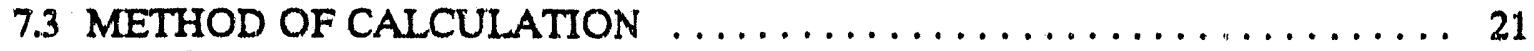

7.4 CONCLUSION $\ldots \ldots \ldots \ldots \ldots \ldots \ldots \ldots \ldots \ldots \ldots \ldots \ldots \ldots, 21$

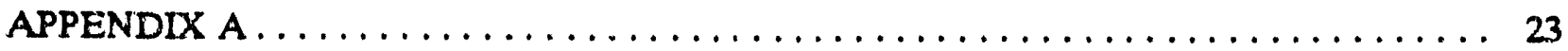

REFERENCES $\ldots \ldots \ldots \ldots \ldots \ldots \ldots \ldots \ldots \ldots \ldots \ldots \ldots \ldots \ldots \ldots \ldots \ldots \ldots \ldots, 25$ 


\section{LIST OF FIGURES}

Figure

Page

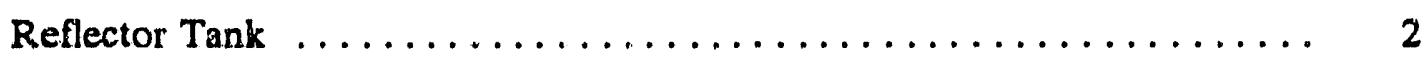

An enlargement of the top of the reflector tank $\ldots \ldots \ldots \ldots \ldots \ldots$

Lockring and wall of the reflector $\ldots \ldots \ldots \ldots \ldots \ldots \ldots \ldots \ldots$

Side view of reactor and some surrounding components

Warm $\mathrm{D}_{2}$ auxiliary tank

11

6

Cold source schematic

\section{IIST OF TABLES}

Table

Seals

Seals

Bolts 


\section{SUMMARY}

This report describes my work as an intern with Martin Marietta Energy Systems, Inc., in the summer of 1991. I was assigned to the Reactor Technology Engineering Department, working on the Advanced Neutron Source (ANS). I worked for K K. Chipley primarily, but also for C. C. Queen, K. D. St. Onge, D. W. Theisen, W. H. Power, M. J. Cole, and R. H. Nelson.

My first project was to select and analyze sealing systems for the top of the diverter/reflector tank. This involved investigating various metal seals and calculating the forces $n$ :cessary to maintain an adequate seal. The force calculations led to an analysis of several bolt patterns and lockring concepts that could be used to maintain a seal on the vessel.

Another project involved some pressure vessel stress calculations and the calculation of the center of gravity for the cold source assembly. I also completed some sketches of possible cooling channel patterns for the inner vessel of the cold source.

In addition, I worked on some thermal design analyses for the reflector tank and beam tubes, including heat transfer calculations and assisting Marc Chandler in Patran and Pthermal analyses.

To supplement the ANS work, I worked with M. J. Cole on other projects. I completed some stress/deflection analyses on several different beams. These analyses were done with the aid of CAASE, a beam-analysis software package.

An additional project involved bending analysis on a carbon removal system. This study was done to find the deflection of a complex-shaped beam when loaded with a full waste can. 


\section{DIVERTER/REFLECTOR TANK: SEALS AND BOLTS}

\subsection{INTRODUCTION AND OBJECTTVES}

The object of this project was to select suitable gaskets for the top of the diverter/reflector tank (Fig. 1) and to calculate the corresponding bolt loads, shear stresses, and deflections.

The reflector vessel is cooled with heavy water, and the reactor pool is filled with light water. The heavy water must not come in contact with the light water or the outside environment. The reflector vessel must, however, be opened remotely to allow for refueling.

The operating conditions included $3 \mathrm{MPa}$ (435 psig) maximum pressure, a temperature of less than $200^{\circ} \mathrm{C}\left(392^{\circ} \mathrm{F}\right)$, and a high radiation environment. We decided to use an all-metal gasket.

Specifications were made to use two gaskets for each of the seal systems (Fig. 2). The inner gasket is considered the primary one; the other is to allow leak detection.

\subsection{PROCEDURE}

The Helicoflex company was consulted for a recommendation on the use of an all-metal seal. Rusty Glasscock, ${ }^{1}$ from the Helicoflex technical department, made the following recommendation:

- Helicoflex model HN-200

- Silver jacket

- Inconel 600 lining

- Nimonic 90 or Inconel 750 spring

- Diameter of $9.4 \mathrm{~mm}(.37 \mathrm{in}$.) for the outer seals

- Diameter of $5.2 \mathrm{~mm}(.20 \mathrm{in}$.) for the inner seals

The calculations for sealing forces were based on the methods and data provided by the Helicoflex company and were checked against American Society of Mechanical Engineers (ASME) standards. The calculations have been slightly modified to accommodate the use of two independent seals in each seal system.

The groove dimensions for each gasket were calculated by the method provided by Helicoflex.

The calculations were then performed to determine the necessary bolting to provide the sealing forces required. Shear stresses were checked to insure that failure would not occur because of bolt loading. Additional calculations, based on the assumption of a simple beam, determined deflections between bolts around the perimeter of the seals.

\section{METHOD OF CALCULATION}

The seals used were as recommended by the Helicoflex company. The required forces were calculated by the method provided by the manufacturer with a change to allow for a double-seal system. These calculations wert also done using the method provided in the ASME boiler code. The answers were the same using both methods.

The calculations of groove dimensions were done as specified by the manufacturer. 


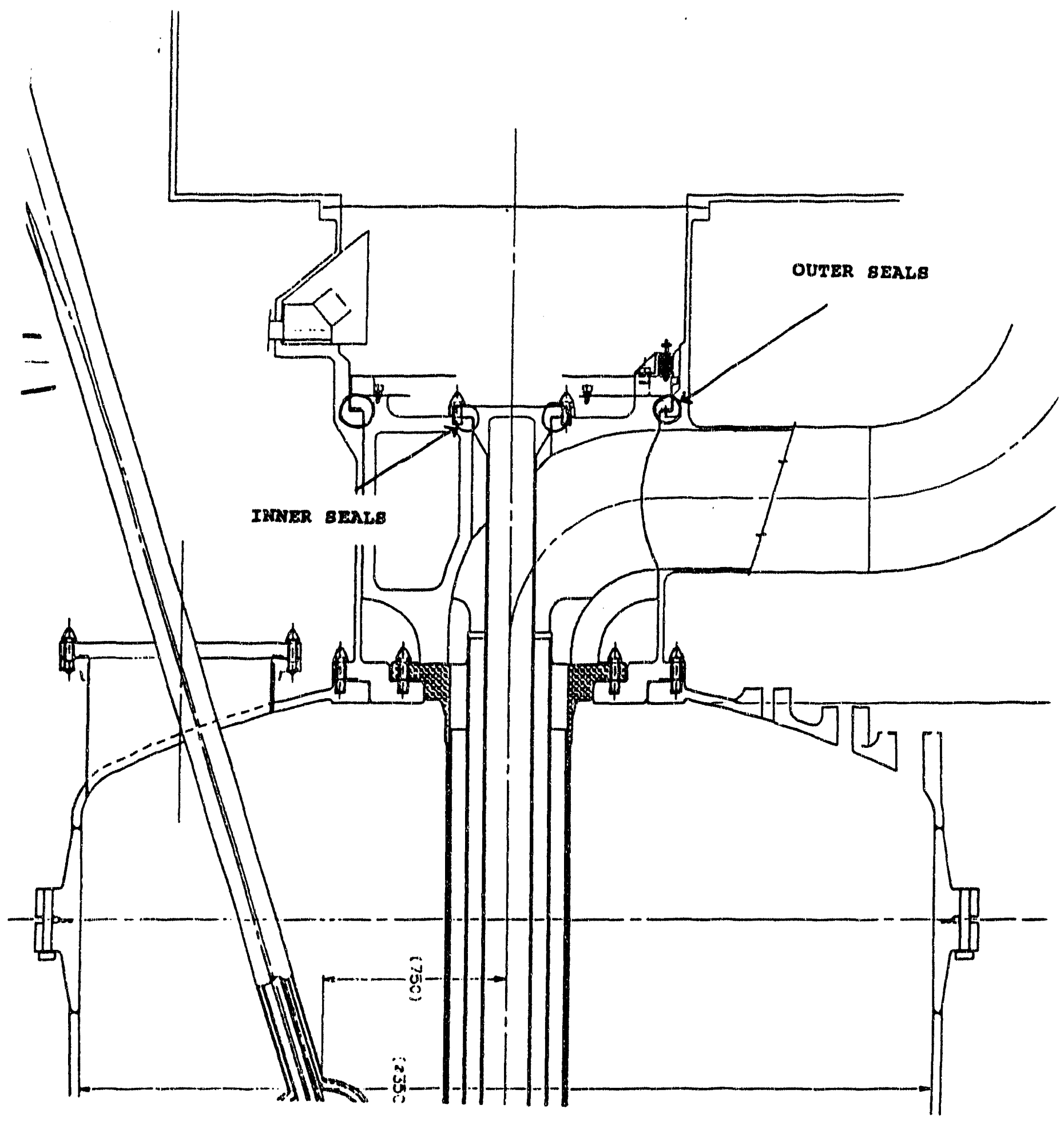

Fig. 1. Reflector Tank This is the top of the reflector tank. The seals being examined are circled and labeled as inner and outer. 


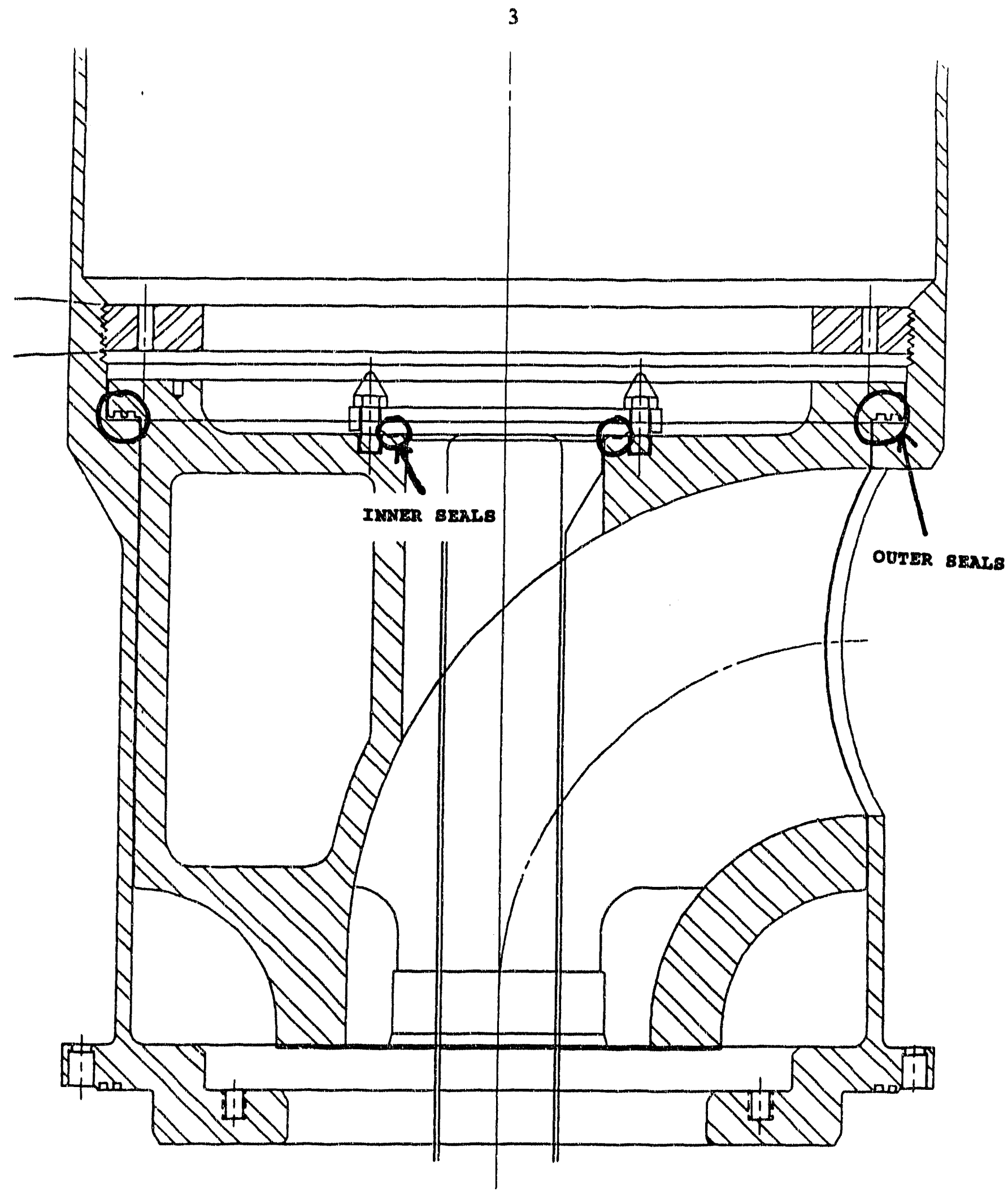

Fig. 2 An enlargement of the top of the reflector tank 
The calculation of bolt stress was based on acceptable stress values from the ASME BPVC and from the reference book, Mechanical Engineering Design. ${ }^{3}$ The bolt spacing was based on recommendations from this book and from the Helicoflex company.

The deflection of the center plug was based on a simple cantilever beam with two fixed ends; the formula is from Rourke. ${ }^{4}$

\subsection{CONCLUSIONS}

The Helicoflex HN-200 all-metal seal has been used for this type of application before and proven acceptable. The calculations also show that it is suitable for this application. It has been shown that the specified bolt configuration will be suitable to maintain the required sealing load. The shear stresses in the sealing systems are not great enough to cause failure. The deflection of the material because of hydrostatic pressure, based on the simple model used, is not great enough to cause leakage.

\subsection{RECOMMENDATIONS}

The Helicoflex HN-200 seal with a silver jacket, Inconel 600 inner lining, and Nimonic 90 or Inconel-750 spring is appropriate for use in the conceptual design (Table 1).

Use 26 bolts with a nominal diameter of $42 \mathrm{~mm}$ (1.65 in.), placed equidistant from each other around the diameter of the seal, to hold the outer seal systern in place (Table 2).

Use 10 bolts with a nominal diameter of $30 \mathrm{~mm}(1.18 \mathrm{in}$.), spaced equally around the perimeter, to hold the inner seal system in place (Table 2).

Table 1. Seaks

\begin{tabular}{lcll}
\hline & \multicolumn{1}{c}{ Sec. diam. } & \multicolumn{1}{c}{ Seal diam. } & \multicolumn{1}{c}{ Sealing force } \\
\cline { 2 - 4 } Helicoflex HN-200 & $5.2 \mathrm{~mm}(.20 \mathrm{in})$. & $36.4 \mathrm{~cm}(14.3 \mathrm{in}$.$) and$ & $121,000 \mathrm{lb}(539.8 \mathrm{kN})$ \\
& & $38.3 \mathrm{~cm}(15.1 \mathrm{in})$. & \\
& & $125.12 \mathrm{~cm}(49.3 \mathrm{in}$.$) and$ & $973,000 \mathrm{lb}$ \\
& $9.4 \mathrm{~mm}(.37 \mathrm{in})$. & $129.59 \mathrm{~cm}(51.0 \mathrm{in})$. & $(432.9 \mathrm{MN})$ \\
\hline
\end{tabular}

Table 2 Bolts

\begin{tabular}{|c|c|c|c|c|}
\hline Number and location & Size & Spacing & Stress & $\begin{array}{l}\text { Allowable } \\
\text { stress }\end{array}$ \\
\hline 10 for inner seal system & $30 \mathrm{~mm}(1.18 \mathrm{in})$. & $135 \mathrm{~mm}$ (5.32 in.) & $\begin{array}{l}86.908 \mathrm{Mpa} \\
(12.6 \mathrm{ksi})\end{array}$ & $\begin{array}{l}140 \mathrm{Mpa} \\
\text { (20 ksi) }\end{array}$ \\
\hline 26 for outer seal system & $42 \mathrm{~mm}$ (1.69 in.) & $168 \mathrm{~mm}$ (6.61 in.) & $\begin{array}{l}\text { 132.143 Mpa } \\
(19.17 \mathrm{ksi})\end{array}$ & $\begin{array}{l}140 \mathrm{Mpa} \\
(20 \mathrm{ksi})\end{array}$ \\
\hline
\end{tabular}




\section{DIVERTER/REFLECTOR TANK: LOCKRING}

\section{INTRODUCTION AND OBJECTTVES}

The object of this project was to perform preiiminary calculations and examine the use of a lockring seal system (Fig. 3 ) for the diverter/reflector tank. This analysis provides a rough estimate of the forces required to use a lockring configuration.

The reactor must be refueled as quickly and as easily as possible. A lockring is needed that can be simply positioned, then rotated to a point where it can provide the necessary sealing forces while being operated remotely.

The Helicoflex seals used for this lockring configuration are the same as those used for the bolt system. The required sealing forces are the same.

The lockring system consists of a lockring held in place by protrusions on the vessel wall. This ring maintains the pressure on the outer set of Helicoflex seals. Only the outer seal set is being considered.

The ring is placed into position and then rotated $10^{\circ}$ to the locked position. It is assumed that a pinion gear will be used to rotate the lockring into position. Rollers are placed to reduce friction and maintain gear contact.

\section{PROCEDURE}

The sealing force data was obtained from a previous report. Arbitrary dimensional values were selected based on the actual dimensions of the vessel. The analysis was to provide a rough estimate of the forces required to use a lockring configuration; therefore, these assumed dimensions were adequate.

The pressure needed to maintain the seals and the angle of rotation to achieve lockring were used as the governing restrictions for the analysis. Based on these parameters and the assumed dimensions, the forces and torques required to lock the ring in place were determined. The placement of the rollers was based on these forces and on a standard pressure angle for involute gears.

\section{METHOD OF CALCULATION}

The force requirements were taken from the seal calculations. The lockring analysis was conducted for an outer lockring holding only the outer seals (Table 3). The dimensions of the pieces were chosen arbitrarily but based on those that have aiready been specified. The coefficient if Eriction used was for aluminum bronze on steel (0.35). This coefficient dictates the angle needed for the system to be self-locking. This angle is $19^{\circ}$. It is desired that the ring be rotated $10^{\circ}$ to lock. This parameter was used rather than the self-locking angle at $19^{\circ}$.

The horizontal force needed to turn the ring was then calculated based on the frictional forces and the downward pressure needed. This horizontal force was translated to a torque on a pinion gear that will be used to rotate the lockring. The torque required by the pinion gear was 1.SES N-M (113,000 ft-libs).

The rollers were placed in positions where they would reduce friction and maintain gear contact while installing and removing the lockring. These positions were based on a standard pressure angle of $22.5^{\circ}$ between the pinion and the inside of the lockring. 


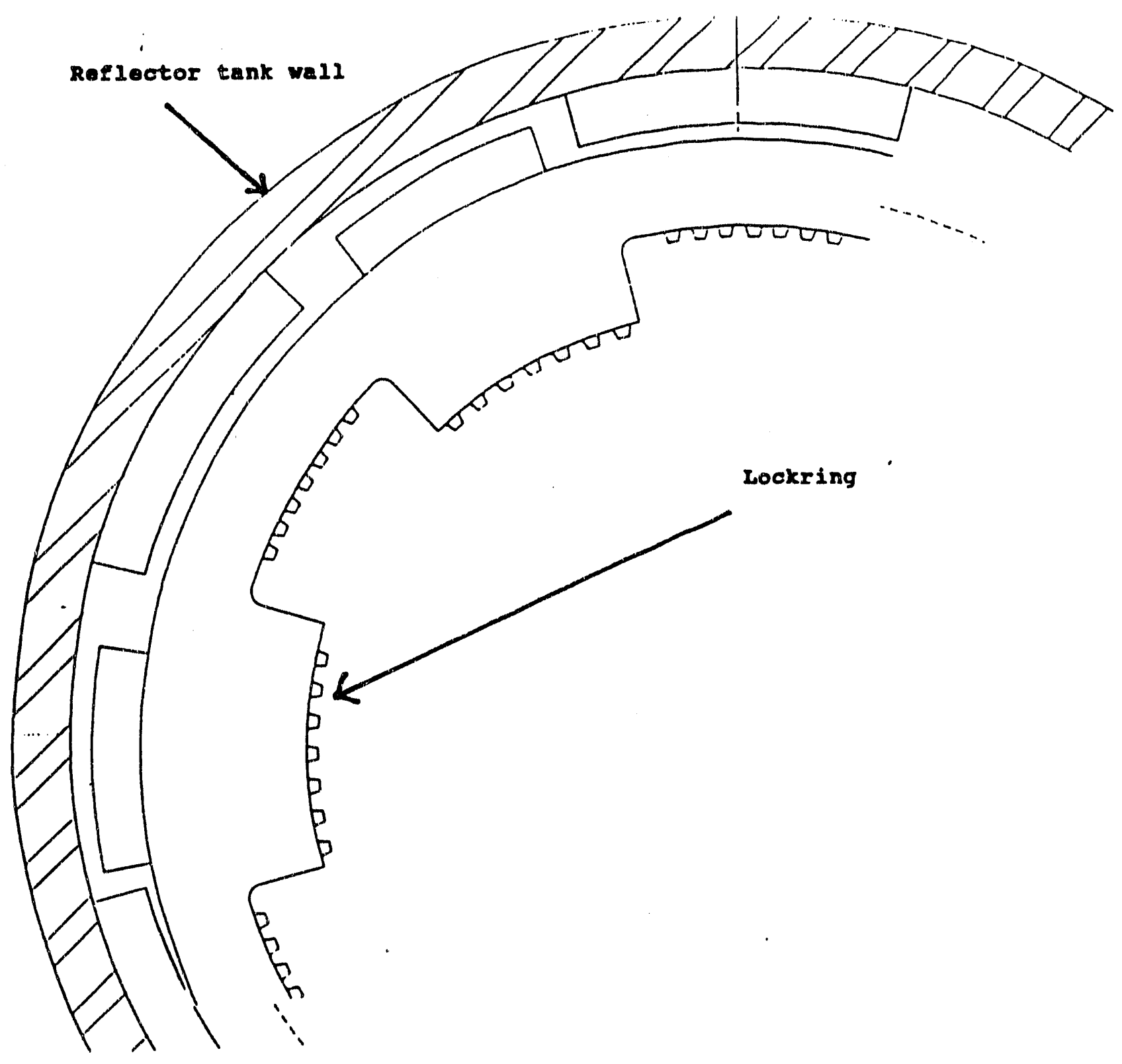

Fig. 3. Lockring and wall of the reflector tank 
Table 3. Lockring

\begin{tabular}{lllll}
\hline & \multicolumn{1}{c}{$\begin{array}{c}\text { Seal } \\
\text { sec. diam. }\end{array}$} & $\begin{array}{l}\text { Compressive } \\
\text { force needed }\end{array}$ & $\begin{array}{c}\text { Horizontal } \\
\text { force needed }\end{array}$ & \multicolumn{1}{c}{$\begin{array}{c}\text { Pinion } \\
\text { torque }\end{array}$} \\
\cline { 2 - 5 } Lockring for outer seal system & $\begin{array}{l}9.4 \mathrm{~mm} \\
(0.37 \mathrm{in} .)\end{array}$ & $\begin{array}{l}4.39 \mathrm{E} 6 \mathrm{~N} \\
(987,000 \mathrm{lb})\end{array}$ & $\begin{array}{l}3.08 \mathrm{E} 6 \mathrm{~N} \\
(692,000 \mathrm{lb})\end{array}$ & $\begin{array}{l}1.5 \mathrm{EE} \mathrm{NM} \\
(113,000 \mathrm{lb}-\mathrm{ft})\end{array}$ \\
\hline
\end{tabular}

\section{CONCLUSION}

The tangential force needed to maintain the seals was 3E8 N (67.4E6 lb). This force translates to a torque of $1.5 \mathrm{E} 5 \mathrm{~N}-\mathrm{M}(113,000 \mathrm{ft}-\mathrm{lbs})$ on the pinion.

The rollers were placed to reduce wall friction and maintain proper gear contact during installation and removal.

A more complete analysis should be done to determine if the forces required are practical. 


\section{COLD SOURCE: WARM D AUXILIARY TANK}

\subsection{INTRODUCTION AND OBIECTIVES}

The purpose of this project was to determine the necessary wall thickness for the cold source warm $D_{2}$ auxiliary tanks (Figs. 4 and 5). The weight of the vessels was also determined.

Two vessels are being considered, one inside the of " Table 4). The inside vessel has an internal pressure of $607.8 \mathrm{kPa}(6 \mathrm{~atm})$ and an external pressure of $0 \mathrm{~Pa}(\mathrm{f} \mathrm{atm})$. The outer vessel has an internal pressure of $0 \mathrm{~Pa}(0 \mathrm{~atm})$ and an external pressure of $101.3 \mathrm{kPa}(1 \mathrm{~atm})$.

\subsection{PROCEDUKE}

Because the calculations were performed to obtain an estimate, the dimensions of the inner and outer vessel are assumed to be the same. The vessels are to be constructed of 3041 stainless steel alloy. It has been dissumed that the maximum stress will be in the middle section of the vessel, not near the end pieces. It has also been assumed that the pressures are the only significant force involved. The allowable stress is assumed to be one half of the yield stress.

The vessels are assumed to be $3.6 \mathrm{~m}(144-\mathrm{in}$.) long with a radius of $91 \mathrm{~cm}(36 \mathrm{in}$.) and hemispherical enul caps (not included in the length).

The weight is determined by multiplying the volume of metal by the deitsity of the metal.

\subsection{METHOD OF CALCULATION}

The material was assumed to be 3041 stainless steel. The allowable stress was assumed to be one half of the yield stress, $103.5 \mathrm{MPa}(15.0 \mathrm{ksi})$.

The vessels were assumed to be thin-walled pressure vessels. The required thicknesses were calculated.

The weight was calculated by multiplying the volume by the density.

Tuble 4. Warm deuterium avociliary tank

\begin{tabular}{|c|c|c|c|c|}
\hline Vessel & Pressure differential & Allowable stress & Required thickness & Weight \\
\hline Inner & $\begin{array}{l}607.8 \mathrm{kPa}(6 \text { atmo }) \text { inside; } \\
0 \mathrm{~Pa}(0 \mathrm{~atm}) \text { outside }\end{array}$ & $103.5 \mathrm{Mpa}(15.0 \mathrm{ksi})$ & $6 \mathrm{~mm}(0.24 \mathrm{in})$ & $9585 \mathrm{~N}(2177 \mathrm{lb})$ \\
\hline \multirow[t]{2}{*}{ Outer } & $\begin{array}{l}0 \mathrm{~Pa}(0 \mathrm{~atm}) \text { inside; } \\
101.3 \mathrm{kPa}(1 \mathrm{~atm}) \text { outside }\end{array}$ & $103.5 \mathrm{Mpa}(15.0 \mathrm{ksi})$ & $1 \mathrm{~mm}(0.004 \mathrm{in})$. & $1600 \mathrm{~N}(359.7 \times(b)$ \\
\hline & & & Total & $11285 \mathrm{~N}(2: 37 \mathrm{Ib})$ \\
\hline
\end{tabular}

\subsection{CONCLUSION}

The inner vessel should be at least 6-nm $(0.24$-in.) thick, and the outer vessel should be at least 1 -min (0.04-in.) thick.

The combined weight of the vessels is $11,285 \mathrm{~N}$ (about $2500 \mathrm{lbs}$ ). 


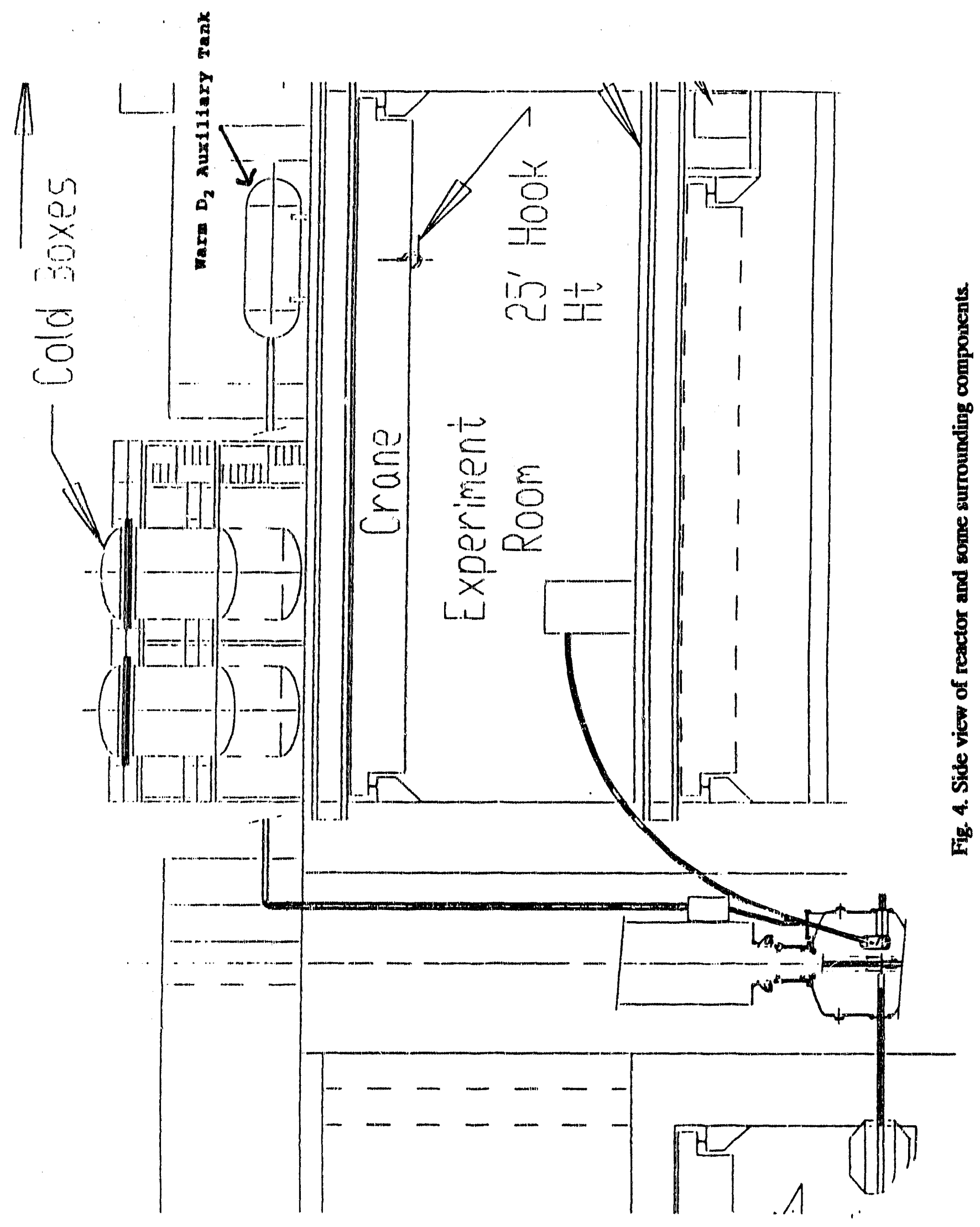




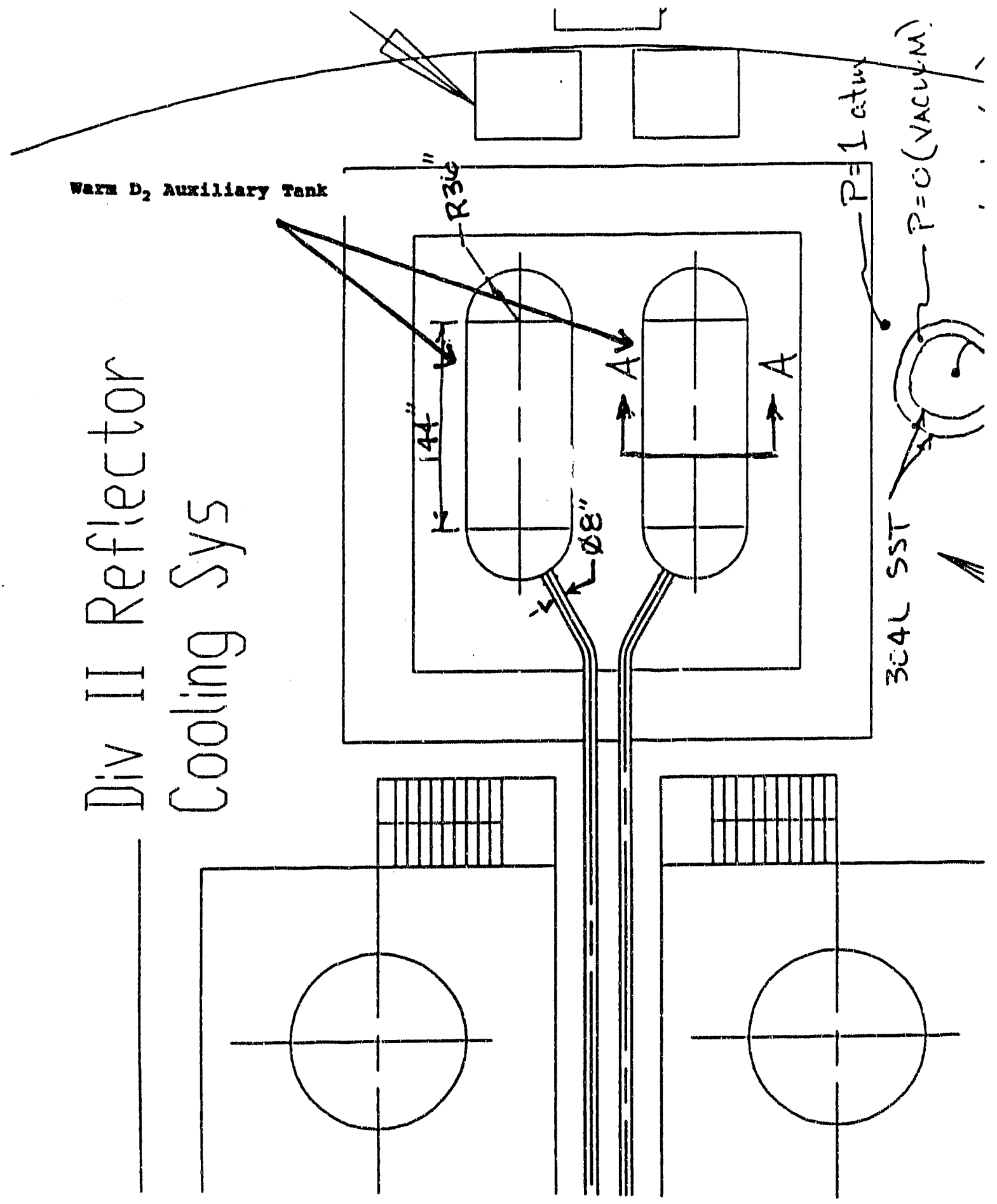

Fig. $\therefore$ Warm $D_{2}$ auxiliary tank 


\section{COLD SOURCE: CENTER OF GRAVITY}

\subsection{INTRODUCTION AND OBJECITVES}

The purpose of this project was to determine the center of gravity of the cold source. The cold source must be removed by lifting it vertically from a single point (Fig. 6). These calculations are not complete. The heat exchanger has not yet been designad; therefore, it is not considered. The calculations will, however, be able to incorporate the heat exchanger data when it becomes available.

\subsection{PROCEDURE}

The cold source was separated into individual components, ano a center of gravity was calculated for each component. The results were combined to find the combined center of gravity for the sum of the components. The center of gravity was calculated for the $\mathrm{X}$ and the $\mathrm{Y}$ directions.

\subsection{METHOD OF CALCULATION}

The cold source was subdivided into sections, and the center of gravity was calculated for each section by finding the mass of a homogeneous section and assuming it to be a point load at the center. This was done for the $\mathrm{X}$ and $\mathrm{Y}$ directions.

The segment centers of gravity were combined by balancing the weight and the distance between the points. This was done with two points, then with the cornbination of the two plus a new one. This process was followed until all of the segments were included. This was done for the $\mathrm{X}$ and $\mathrm{Y}$ directions.

Note: See Fig. 6 for the location of the "zero" point. All measurements are relative to this point.

\subsection{CONCLUSION}

The center of gravity in the X (horizontal) direction was $21.8 \mathrm{~cm}(8.6 \mathrm{in}$.) to the right of the zero point (see Fig. 6). The center of gravity in the $Y$ (vertical) direction was $110.9 \mathrm{~cm}$ (43.7 in.) above the zero point. The total weight was $117 \mathrm{~kg}(260.5 \mathrm{lbs})$. 


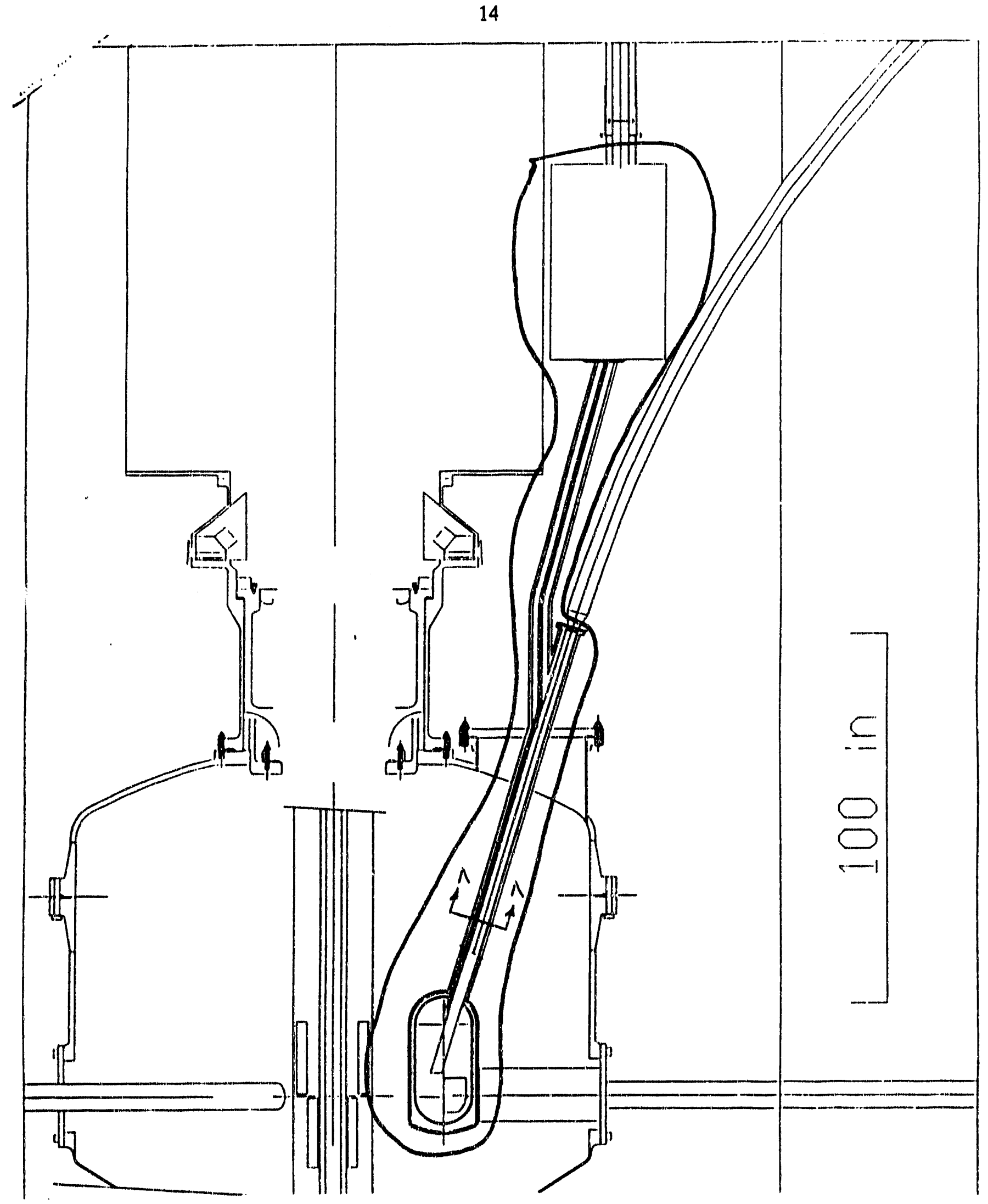

Fig. 6. Cold source schematic. 


\section{BEAM TUBE COOLING}

\subsection{INTRODUCTION AND OBJECTTVES}

The purpose of this project is to analyze the cooling of beam tubes given specified heat generation rates, fluid flows, and fluid temperatures. Beam tubes in the reflector tank absorb radiation and thus generate heat. The tubes need to be cooled.

\subsection{PROCEDURE}

The beam tubes are elliptical with a major axis of $200 \mathrm{~mm}(7.87 \mathrm{in}$.), a minor axis of $100 \mathrm{~mm}$ (3.94 in.), and a thickness of $12 \mathrm{~mm}(0.47 \mathrm{in}$.). The heat transfer was modeled as a flat plate. The analysis began with the calculation of the heat gescration. The process must be steady-state; therefore, all of the heat generated within the tubes must be transferred to the fluid.

The first constraint used was the inner wall temperature of $90^{\circ} \mathrm{C}\left(194^{\circ} \mathrm{F}\right)$. The outer surface temperature was calculated from the inner surface temperature and the required heat transfer. The amount of heat transferred to the fluid was then calculated. The conditions of the fluid, temperature, and velocity were then varied to examine the possibilities for improving heat transfer.

The use of the flat plate model is not completely accurate; it will not show the "hot spots" where the velocity varies from the mean. In some cases, the fluid properties are not exact for the given temperatures, but this will not affect the results. The results were to see if the process was feasible; then a more accurate model will be developed.

\subsection{METHOD OF CALCULATION}

One half of the circumference of the ellipse was calculated as the height of the plate. The mean flow velocity was calculated from the dimensions of the tank and the volumetric flow rate that was provided.

The Reynolds number, Prandlt number, and Nusseit number were calculated. These values were used to find a mean convection coefficient.

The inside wall temperature was used to calculate an outside wall temperature assuming conduction. This temperature was used with the known fluid temperature to calculate the heat transfer to the fluid. This value was compared to the heat generation rate. The vilues must be equal for the process to be steady-state.

\subsection{CONCLUSION}

The rate of generation and the rate of convection were not equal. The rate of generation was greater even with the smallest rate given.

This analysis must be continued to achieve a convection rate equal to the gerreration rate. If the aluminum is allowed to get hotter and/or the flow rate is increased, the rates will converge. The analysis should be continued until these rates are equal. When the rates are equal, the model will need to be modified to account for the local velocities around the surface. The 
velocity will probably be lower at the ends of the surface. Thus, the heat transfer rate will be lower, and the local temperatures will rise. This problem may be solved if the thickness of the guide tubes can be varied so that they are thinner where the velocity is lower, to reduce the heat generation in those areas. 


\section{BEAM ANALYSIS}

\subsection{INTRODUCTION AND OBJECTTVES}

The object of this report was to analyze the deflections and stresses in two beams (Table 5). The beams are the b4 beam and the b1 beam shown in Fig. 7. The two support columns are to be removed from the Bumpy Torus structural framing.

\section{PROCEDURE}

The beams were analyzed with a variety of loading variations using CAASE software. The loads were calculated by computing the weights of the lead panels that must be supported by the beams. The weight distributions were calculated and applied to the beams.

\subsection{METHOD OF CALCULATION}

The b1 beam was analyzed first, using CAASE. The analysis was performed by first calculating the weights of the lead tiles and the points where the weights acted on the beams. The data for the dimensions were taken from previous calculations done by M. J. Cole.

The analysis was performed as though all of the weight from each tile acted on the beam. The maximum deflection was found to be $-8.636 \mathrm{~mm}(-3.4 \mathrm{E}-1 \mathrm{in}$.); the maximum bending moment was found to be 3.05E4 Nm (-2.7ES in.-lbs); and the maximum shear force was $-5.34 \mathrm{EA} \mathrm{N}(1.2 \mathrm{E} 4 \mathrm{lbs})$. These values show a bending stress of $1.31 \mathrm{E8} \mathrm{N} / \mathrm{m}^{2}\left(1.9 \mathrm{EA} \mathrm{lbs} / \mathrm{in}^{2}\right)$ and a maximum shear stress of $1.586 \mathrm{E} 7 \mathrm{~N} / \mathrm{m}^{2}\left(2.3 \mathrm{E} 3 \mathrm{lbs} / \mathrm{in}{ }^{2}\right)$. This was considered too conservative, and another, less conservative approach was taken.

Each lead tile was assumed to be a beam acting over the supports on which it rests so that a proportional amount of the weight could be found for each of the beams supporting it.

The analysis was performed assuming that the proportional loads were distributed over the eatire length of the beam. The largest value for each segment was used for the weight of each tile and multiplied by the number of tiles to find the total force on the particular bearn segment. This value was divided by the length of the beam to yield the distributed load. The maximum deflection was $-2.918 \mathrm{~mm}$ (-1.149E-1 in.); the maximum bending moment was $1.64 \mathrm{E} 4 \mathrm{Nm}$ (1.45E5 in.-Ibs); and the maximum shear force was 2.36E4 N (5.3E3 lbs). All of these maximum values occurred in the center segment of the beam.

Further analysis used superposition of the proportional loads at the center of each tile for the end segments of the beam and a distributed load in the center segment of the beam. The maximum deflection was $-1.806 \mathrm{~mm}(-7.11 \mathrm{E}-2 \mathrm{in}$.); the maximum bending moment was 1.15EA Nm (1.02E5 in.-lbs); and the maximum shear force was -1.908E4 N (-4.29E3 lbs). All of the maximum values were again found to be in the center segment of the beam.

Another analysis used the point proportional loads superimposed in all segments of the beam. The maximum deflection was $-2.210 \mathrm{~mm}(-8.7 \mathrm{E}-2 \mathrm{in}$.); the maximum bending moment was $1.19 \mathrm{E} 4 \mathrm{Nm}$ (1.05ES in.-lbs); and the maximum shear force was 1.913E4 N (4.3E3 lbs). All of the maximum values were found to be in the center segment of the beam. 


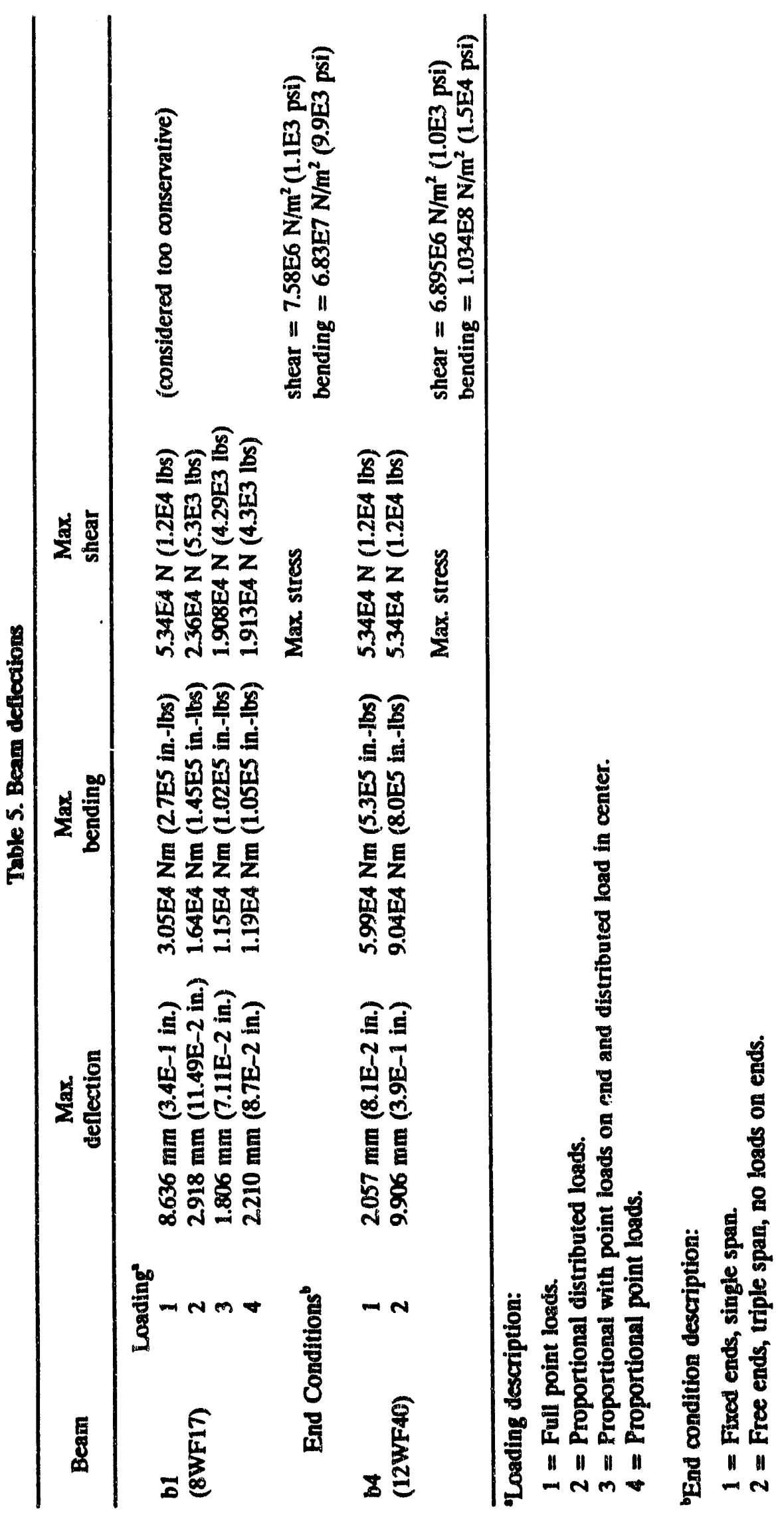




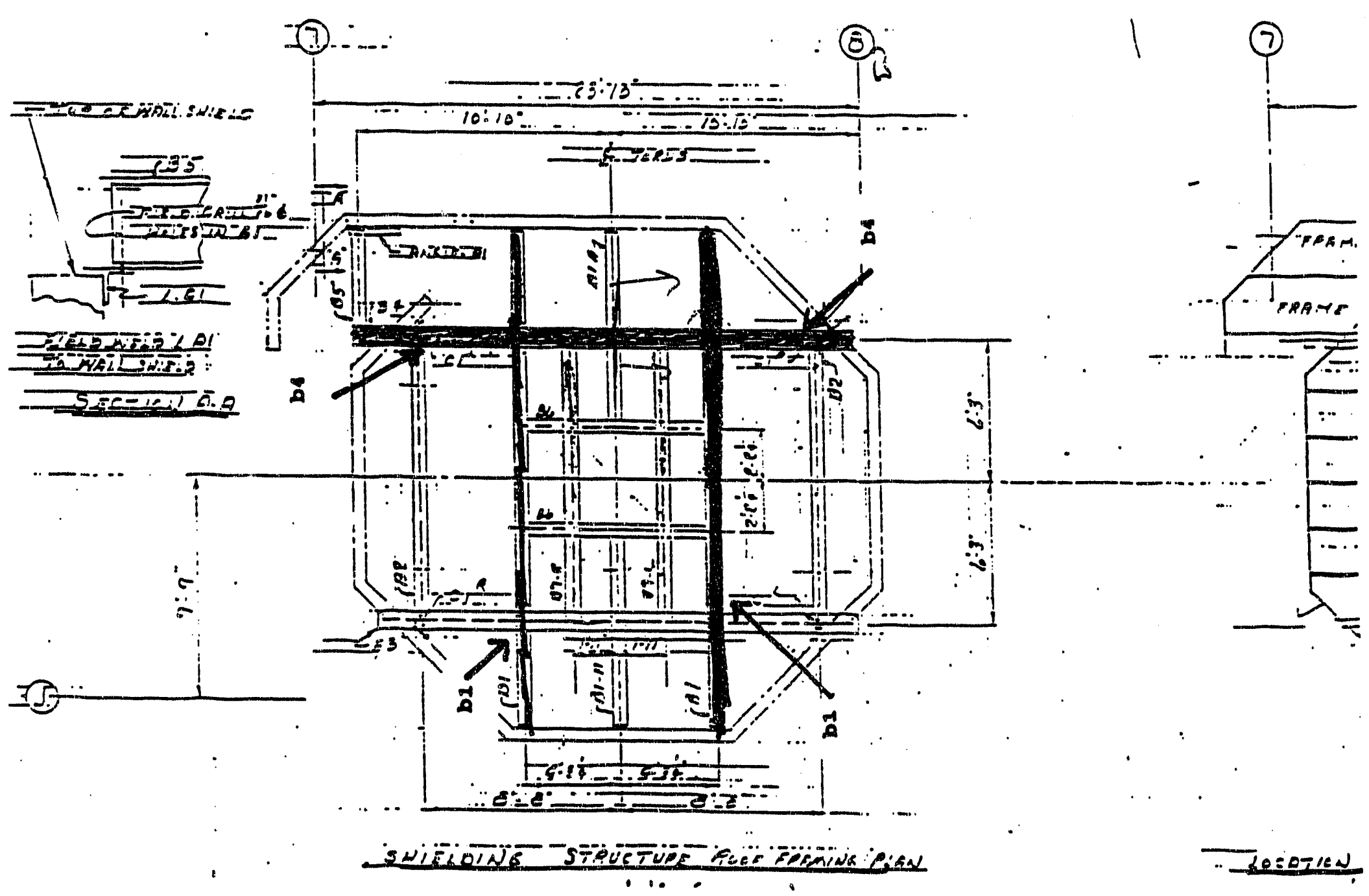

Fig. 7. Beam Layout. This figure shows the beam layout of the beams to be analyzed. These beams are loaded with lead panels on top of them. 
The beam is an 8 wide flange (WF) 17. The cross-sectional area is $32.32 \mathrm{~cm}^{2}\left(5.01 \mathrm{in}^{2}\right)$; the height is $20.38 \mathrm{~cm}$ (8 in.); and the moment of inertia is $2.356 \mathrm{E} 3 \mathrm{~cm}^{4}\left(56.6 \mathrm{in.}{ }^{4}\right)$. Using the largest values (with the exception of the first analysis), the bending stress is calculated to be $6.83 \mathrm{E} 7 \mathrm{Nm}^{2}$ (9.9E3 lbs/in. ${ }^{2}$ ), and the maximum shear stress is to be $7.58 \mathrm{E} 6 \mathrm{Nm}^{2}\left(1.1 \mathrm{E} 3 \mathrm{lbs} / \mathrm{in} .{ }^{2}\right)$.

The second analysis was performed on the b4 beam using CAASE and data from previous calculations. The loads were calculated for each loading point, and the analysis was run using two different types of end conditions. Sketches on the data sheet describe the exact end conditions used. For the first set; the maximum deflection was $-2.057 \mathrm{~mm}(-8.1 \mathrm{E}-2 \mathrm{in}$.); the maximum moment was $-3.99 \mathrm{ES} \mathrm{Nm}(-5.3 \mathrm{E} 5 \mathrm{in}$. $\mathrm{lbs})$; and the maximum moment was $-9.04 \mathrm{ES} \mathrm{Nm}$ (-8.0E5 in.-lbs); and the maximum shear force was $-5.338 \mathrm{E} A \mathrm{~N}(-1.2 \mathrm{EA} \mathrm{lbs})$. For the second set, the maximum deflection was $-9.906 \mathrm{~mm}(-3.9 \mathrm{E}-1 \mathrm{in}$.); the maximum moment was $-9.04 \mathrm{ES} \mathrm{Nm}$ (-8.0E5 in.-lbs); and the maximum shear force was -5.338E4 N (-1.2E4 lbs).

This beam was a 12 WF 40 . The cross-sectional area is $76.13 \mathrm{~cm}^{2}\left(11.8 \mathrm{in}^{2}\right)$; the height is $30.33 \mathrm{~cm}$ (11.94 in.); and the moment of inertia is $1.29 \mathrm{EA} \mathrm{cm}^{4}\left(310 \mathrm{in} .{ }^{4}\right)$. Using the larger values from the analysis of each set of end conditions, the maximum bending stress was $1.034 \mathrm{E} 8 \mathrm{Nm}^{2}$ (1.54E4 lbs/in. $\left.{ }^{2}\right)$. The shear stress is $6.895 \mathrm{E} 6 \mathrm{Nm}^{2}\left(1.0 \mathrm{E} 3 \mathrm{lbs} / \mathrm{in}^{2}\right)$.

\subsection{CONCLUSION}

The analysis of the b4 beam was performed by a number of different methods. The first method, with the total weights on the beam, was considered too conservative. The weight was then distributed among all of the supporting beams. The other three methods yielded deflections between $2.54 \mathrm{~mm}(0.1 \mathrm{in}$.) and $1.778 \mathrm{~mm}(0.07 \mathrm{in}$.). The bending moments ranged from $1.19 \mathrm{E} 4 \mathrm{Nm}(1.05 \mathrm{ES})$ to $1.64 \mathrm{E} 4 \mathrm{Nm}$ (1.45E5 in.-lbs), and the shear force was between 1.913E4 N (4300 lbs) and 2.36E4 N (5300 lbs).

The $b 1$ beam was analyzed using two different end conditions. The first was using a single span beam with fixed ends. The maximum deflection for this method was $2.032 \mathrm{~mm}(0.08 \mathrm{in}$.). The second was using a multispan beam with free ends. The deflection was $9.906 \mathrm{~mm}$ (0.39 in.). 


\section{CARBON REMOVAL CAN}

\subsection{INTRODUCTION AND OBJECTIVES}

The purpose of this project was to determine the deflection of a structure used to support a carbon removal can (Fig. 8). The can is loaded with approximately $45 \mathrm{~kg}$ (100 lbs), then rotated out from under the loading area and removed. If the structure deflects enough to touch the floor it is unusable.

\subsection{PROCEDURE}

A first set of calculations was performed with the assumption that the whole system is a flat plate, and the load is concentrated in the center of the loading area.

A second set of calculations was performed assuming that the load was in the center of the loading area and that a person [approximately $90 \mathrm{~kg}(200 \mathrm{lbs})]$ was standing on the end of the structure. This analysis assumed the structure was a flat plate.

A third set of calculations was performed with the actual geometries of the structure (with a few minor simplifications) and the load in the center of the loading area.

A fourth set of calculations was performed with the actual geometries, the load in the loading area, and the person standing on the end of the structure.

Note that the person standing on the structure constitutes misuse and that the structure is not intended or designed for this.

\subsection{METHOD OF CALCULATION}

The first set of calculations was performed as though the system was a simple cantilever beam. This was a very conservative estimate. The deflection was $2 \mathrm{~cm}(0.8 \mathrm{in}$.) with the load alone. Equations from Rourke ${ }^{4}$ were used.

The second set of calculations used a less conservative and more realistic estimate. The area moment method was used. The moments of inertia were calculated for each different section. In the sections with changing cross-sectional areas, the section was divided into segments, and the average cross section was used. The shear and moment diagrams were drawn and then the M/EI diagram. The deflections were calculated for each segment and summed to find the total deflection. This calculation was done with the anticipated load of $45 \mathrm{~kg}(100 \mathrm{lbs})$ and with the addition of a $90-\mathrm{kg}(200-\mathrm{lb})$ person on the end of the structure. The deflection under the proper anticipated use is $0.058 \mathrm{~cm}(0.023 \mathrm{in}$.). The estimate with the $90-\mathrm{kg}(200-\mathrm{lb})$ person causes a deflection of $2.28 \mathrm{~cm}(0.9 \mathrm{in}$.).

\subsection{CONCLUSION}

The deflections based on the flat plate assumption were $2.03 \mathrm{~cm}(0.8 \mathrm{in}$.) for the intended load alone and $11.8 \mathrm{~cm}(4.6 \mathrm{in}$.) with the addition of a $90 \mathrm{~kg}(2.00-\mathrm{lb})$ person on the end of the structure. 
The deflections using the actual geometry were $0.058 \mathrm{~cm}(0.023 \mathrm{in}$.) with the load alone and $2.28 \mathrm{~cm}$ (0.9 in.) with the person on the end.

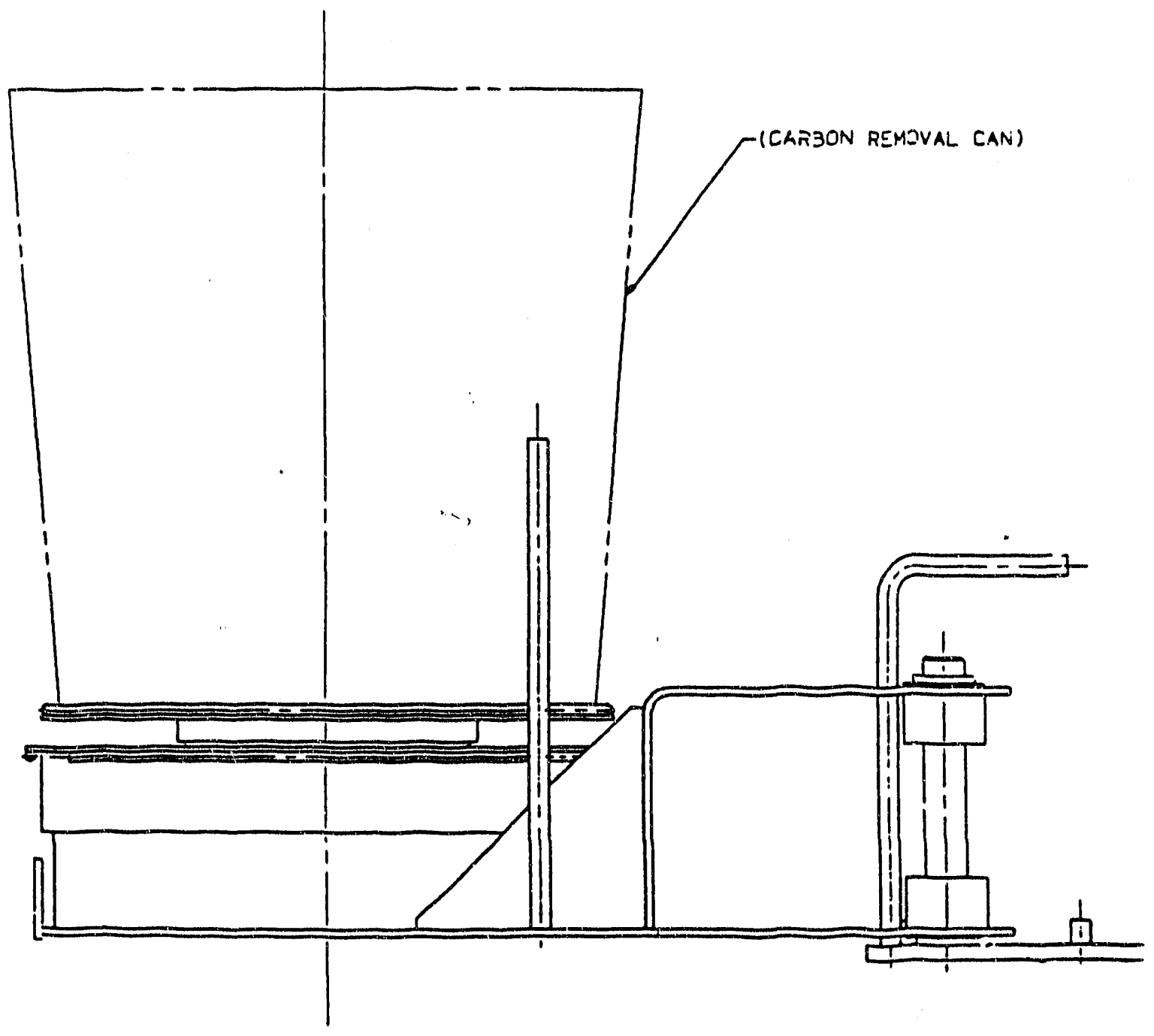

Fig. 8. Carbon removal system. 


\section{APPENDIX A}

The projects discussed previously cover the majority of the detailed work that I have done this summer. Other smaller projects will be mentioned briefly here in the Appendix.

A current concept is to force a fluid through flow channels around the exterior to cool the cold source on the outside. I helped D. W. Theisen sketch some of the patterns that could be used for the flow channels.

I did some other small-beam analysis problems for M. J. Cole.

Because finite element analysis interests me, I watched the instructional video tapes for Patran. I watched the first seven tapes, which taught me enough to do some geometric models. Marc Chandler and I worked on some models for PThermal analysis and on a model for a Nastran stress analysis.

In addition to Patran, I learned to use MathCad, CAASE, Professional Cadam, and a RISC system/6000. 


\section{REFERENCES}

1. R. Glasscock, Helicoflex Components Division, private communication to S. K. Marland, Martin Marietta Energy Systems, Inc., July 1991.

2. ASME Boiler and Pressure Vessel Code, Sect. VIII, Div. 1, American Society Mechanical Engineers, New York, 1989.

3. J. E. Shigley et al., Mechanical Engineering Design, 5th ed., McGraw-Hill, New York, 1989.

4. R. Rourke, Formulas for Stress and Strain, McGraw-Hill, New York, 1965. 


\section{INTERNAL DISTRIBUTION}

1. C. W. Alexander

2. D. J. Alexander

3. R. R. Allen

4. R. G. Alsmiller

5. T. L Anderson

6. B. R. Appleton

7. J. W. Baker

8. R. E. Battle

9. R. S. Booth

10. W. W. Bowman

11. R. A. Brown

12. G. J. Bunick

13. J. H. Campbell (5)

14. P. F. Cento

15. N. C. J. Chen

16. J. E Cleaves

17. J. T. Cleveland

18. G. L. Copeland

19. B. L. Corbett

20. J. R. Dixon

21. A. P. Duncan

22. F. F. Dyer

23. W. W. Engle

24. D. K. Felde

25. R. E. Fenstermaker

26. G. F. Flanagan

27. R. K. Genung

28. M. L. Gildner

29. H. A Glovier

30. S. D. Hall

31. R. M. Harrington

32. J. B. Hayter

33. S. R. Holliman

34. D. T. Ingersoll

35. J. A. Johnson

36. R. L Johnson

37. M. Kaminaga

38. R. A. Lillie

39. M. A. Linn

40. J. A March-Leuba
41-43. G. Mariand ( 3 copies)

44. B. S. Maxon

45. G. T. Mays

46. T. J. McManamy

47. G. R. McNutt

48. B. H. Montgomery

49. R. M. Moon

50. D. G. Morris

51. T. F. Orlin

52. R. E. Pawel

53. F. J. Peretz

54. A. R. Perkins

55. R. T. Primm, III

56. C. C. Queen

57. S. Raman

58. J. S. Rayside

59. J. P. Renier

60. A. E. Ruggles

61. T. L. Ryan

62. D. L. Selby

63. H. B. Shapira

64. M. Siman-Tov

65. B. H. Singletary

66. K D. St. Onge

67. R. P. Taleyarkhan

68. P. B. Thompson

69. K. R. Thoms

70. S. R. Tompkins

71. D. B. Trauger

72. B. D. Warnick

73. C. D. West

74. J. L. Westbrook

75. B. A. Worley

76. G. T. Yahr

77. G. L. Yoder

78. A. Zucker

79. ORNL Patent Office

80-81. Laboratory Records

82. Laboratory Records (RC) 


\section{EXTERNAL DISTRIBUTION}

83. R. Awan, U.S. Department of Energy, NE-473, Washington, DC 20585.

84. C. L. Christen, DRS/Hundley Kling Gmitter, FEDC, MS-8218, P.O. Box 2009, Oak Ridge, TN 37831-8218.

85. R. R. Fullwood, Brookhaven Nutional Laboratory, Upton, NY 11973.

86. W. R. Gambill, Route 5, Box 226, Clinton, TN 37716.

87. B. Gupta, AECL Technologies, 1155 Metcalfe Street, 2nd Floor, Montreal, Quebec, Canada H3B 2 V6.

88. A. F. Henry, Professor, Department of Nuclear Engineering, Massachusetts Institute of Technology, 77 Massachusetts Avenue, Cambridge, MA 02139.

89. R. A Hunter, Director, Office of Facilities, Fuel 7ycle, and Test Programs, Nuclear Energy Division, U.S. Department of Energy, NE-47, Washington, DC 20585.

90. L. C. Ianniello, Acting Associate Director, Office of Basic Energy Sciences, Office of Energy Research, U.S. Department of Energy, ER-10, Washington, DC 20585.

91. T. L. Kerlin, University of Tennessee, College of Engineering, 315 Pasqua Engineering Building, Knoxville, TN 37996-2300.

92. J. D. Kling, DRS/Hundley Kling Gmitter, Architects/Planners, One Gateway Center, Pittsburgh, PA 15222.

93. J. A. Lake, Manager, Nuclear Engineering and Reactor Design, Idaho National Engineering Laboratory, P.O. Box 1625, Idaho Falls, ID 83415.

94. W. F. Manning, U.S. Department of Energy, Oak Ridge Field Office, FEDC, MS8218, P.O. Box 2009, Oak Ridge, TN 37831-8218.

95-96. W. E. Meek, Project Manager, Gilbert/Commonwealth, Inc., P.O. Box 1498, Reading, PA 19603.

97. W. T. Oosterhuis, Materiais Sciences Division, Office of Basic Energy Sciences, Office of Energy Research, U.S. Department of Energy, ER-132, Washington, DC 20585.

98. H. Patrick, Department of Engineering Science and Mechanics, the University of Tennessee, Knoxville, TN 37916.

99. H. Preble, Research and Test Reactor Fuel Elements, Babcock and Wilcox Co., P.O. Box 785, Lynchburg, VA 24505.

100. J. M. Ryskamp, Idaho National Engineering Laboratory, P.O. Box 1625, Idaho Falls, ID 83415.

101. J. L. Snelgrove, Coordinator, Engineering Applications, RERTR Program, Argonne National Laboratory, 9700 South Cass Avenue, Argonne, IL 6,iv39.

102. I. L. Thomas, Director, Materials Science Division, Office of Energy Research, U.S. Department of Energy, ER-13, Washington, D.C. 20585.

103. R. P. Wadkins, Idaho National Engineering Laboratory, P.O. Box 1625, Idaho Falls, ID 83415.

104. J. M. Warren, Gilbert/Commonwealth, Inc., 1055 Commerce Park Drive, Suite 200, Oak Ridge, TN 37830.

105. D. K. Wilfert, Energy Programs, U.S. Department of Energy, Oak Ridge Field Office, FEDC, MS-8218, P.O. Box 2009, Oak Ridge, TN 37831-8218.

106. P. W. Winkler, Air Products and Chemicals, Inc., 7201 Hamilton Boulevard, Allentown, PA 18195-1501.

107-118. Office of Scientific and Technical Information, P. O. Box 62, Oak Ridge, TN 37831 

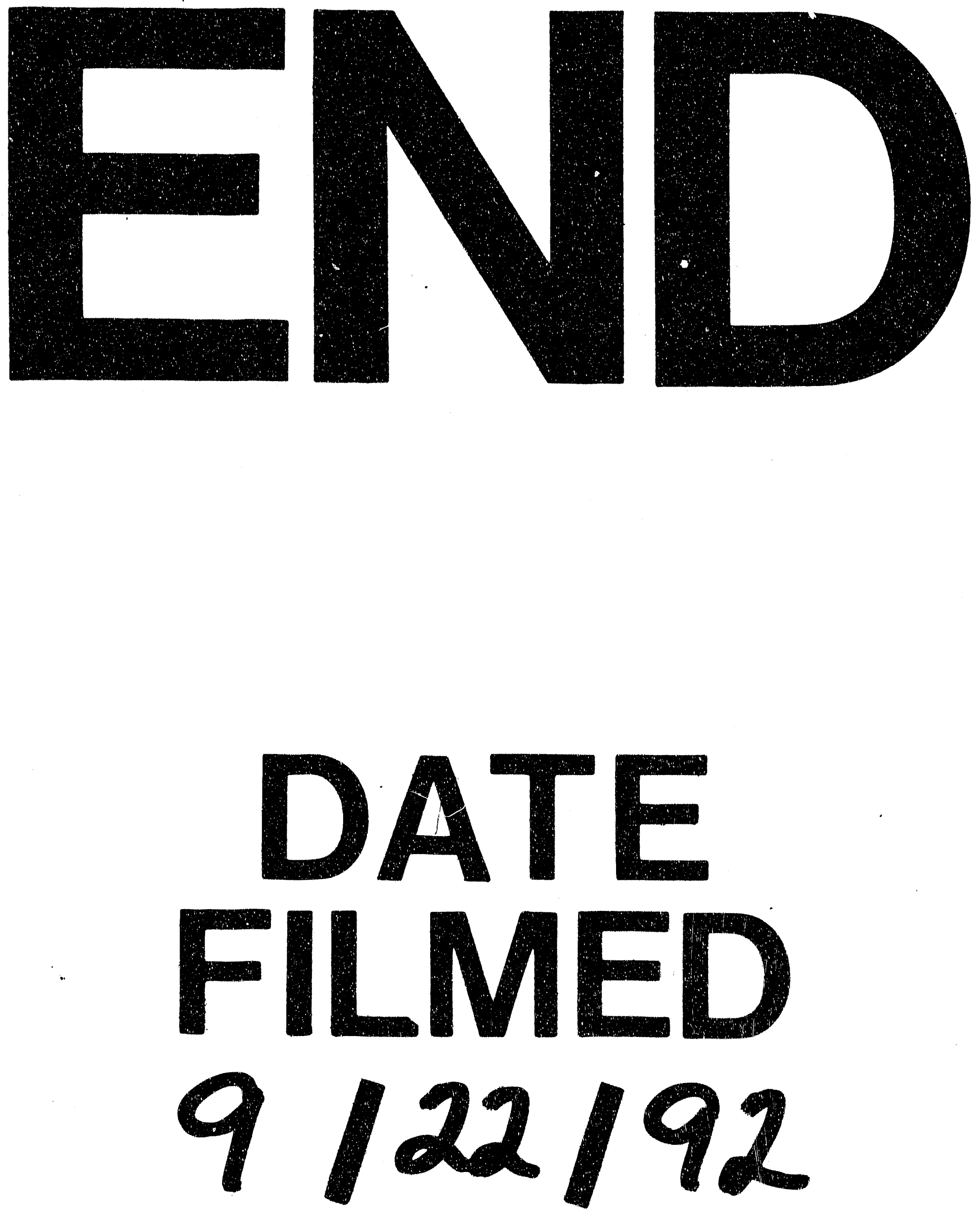
